\title{
CYP11A1 wt Allele
}

National Cancer Institute

\section{Source}

National Cancer Institute. CYP11A1 wt Allele. NCI Thesaurus. Code C52318.

Human CYP11A1 wild-type allele is located within 15q23-q24 and is approximately $30 \mathrm{~kb}$ in length. This allele, which encodes cytochrome P450 11A1, mitochondrial protein, is involved in steroid synthesis. Certain allelic variants of the CYP11A1 gene result in 17alpha-hydroxylase/17,20-lyase deficiency. Defects in this gene cause congenital adrenal insufficiency and cong enital lipoid adrenal hyperplasia. 